\title{
Improvement of the System of Diagnostics of Metal Structures and Mechanisms of Foundry Cranes
}

\author{
Penchuk Valentin Alekseevich ${ }^{1}$, Sidorov Vladimir Anatolyevich ${ }^{2}$ \\ ${ }^{1}$ Department of Land Transport and Technological Complexes and Facilities, Mechanical Faculty, State Educational Institution of Higher \\ Professional Education "Donbas National Academy of Civil Engineering and Architecture", Makeevka, Donetsk People's Republic \\ ${ }^{2}$ Department of Mechanical Equipment of Ferrous Metallurgy Plants, Faculty of Mechanical Engineering, State Educational Institution of \\ Higher Professional Education "Donetsk National Technical University", Donetsk, Donetsk People's Republic
}

\author{
Email address: \\ penshyk@rambler.ru (P. V. Alekseevich)
}

\section{To cite this article:}

Penchuk Valentin Alekseevich, Sidorov Vladimir Anatolyevich. Improvement of the System of Diagnostics of Metal Structures and Mechanisms of Foundry Cranes. International Journal of Materials Science and Applications. Vol. 10, No. 4, 2021, pp. 87-93.

doi: $10.11648 /$ j.ijmsa.20211004.12

Received: July 17, 2021; Accepted: August 2, 2021; Published: September 10, 2021

\begin{abstract}
Periodic assessment of the technical condition of mechanisms and metal structures of foundry cranes is insufficient to ensure the reliability of the technogenic system of metallurgical production with long operating resources. Overviewing a crane as a set of rateresource elements with different recovery periods and regular control make it possible to set a range of optional and functional diagnostic parameters with regular inspection and constant control of technical condition of foundry cranes. The foundry crane is considered as an interaction of subsystems for which the operating conditions, characteristic damages and defects are determined. For diagnostics, the application of the following methods is considered: visual, visual-optical, vibration, thermal, non-destructive testing methods in the general structure of measures to maintain and restore the working condition of metallurgical cranes. Control and assessment of the condition of hawser, metal structures, lifting and movement mechanisms, automation systems are considered. The duplication of the strain monitoring system is carried out by the acceleration control system of metal structures - which allows to estimate the loads impact on the metal structure by the value of accelerations, which serves as the basis for the load cycle counter. The use of organoleptic methods, the installation of fixed systems and methods for periodic monitoring using portable instrumentation and multichannel systems, such as complex UMS-16 in conjunction with the SAFE PLANT allows to provide maintenance service information, prevents injuries, developing at different speeds.
\end{abstract}

Keywords: Technical Condition, Foundry Crane, Diagnostic Parameter

\section{Introduction}

The problem. Foundry cranes used in the metallurgical industry are considered as an integral part of the technological process, ensuring its continuity during certain operations.

The technical condition of the complex of mechanisms, elements and metal structures of the foundry crane is determined periodically during technical and expert inspections. This is not enough to ensure the reliability of the technogenic system of metallurgical production with long operating resources. Overviewing a crane as a set of rateresource elements with different recovery periods make it possible to set a range of optional and functional diagnostic parameters with regular inspection and constant control of technical condition of foundry cranes.

Analysis of recent research and publications. The occurrence of an additional furnace-ladle unit in the technological cycle of metallurgical production raised productivity in steelmaking, increased the intensity of foundry cranes use. The increase in the height of electric steelmaking and converter machines required an increase in the lifting speed to reduce the overall melting cycle, therefor it led to an increase in the number of failures of the lifting mechanism, which was indirectly expressed by the appearance of drive design options [1].

The need to control indirect indicators-noise and vibration by meanes of organoleptic or instrument methods is indicated 
in regulatory documents $[2,3]$. There are known studies of the movement mechanisms vibration of overhead cranes [4, 5], which used wireless and wired measuring systems. Dynamic loads that occur in the metal structure during the movement of the crane are considered in $[6,7]$. The problem of installing stationary vibration control systems on the mechanisms of the bridge crane is a solvable problem [8], but general concepts are not formulated for measuring the vibration parameters of the main lift gearboxes located on an elastic base.

Experience in assessing the technical condition of overhead cranes, summarized in [9], indicates the effectiveness of using non-destructive testing methods (capillary, magnetic, acoustic, eddy current, and others in addition to visual inspection. Separately, the effectiveness of the acoustic emission method in detecting cracks is indicated. It was found that increased vibration leads to an accelerated growth of cracks in the details of metal structures, reducing the overall service life of the crane $[10,11]$.

There is a constant interest in improving the reliability of foundry metallurgical cranes [12], which is expressed in the defense of candidate and doctoral dissertations. The subject of research is related to: assessment of operational risk and safety management; diagnostics of metal structures damage; prediction of safe working conditions during operation; studies of thermal interaction on metal structures and ropes [13-17]; assessment of the load-bearing capacity of elements of metal structures of bridge cranes, etc. The main arguments for the research relevance are: the worn-out fleet of bridge cranes; the lack of funds for updating, reconstruction and modernization; progressive indicators of the growth of accidents and industrial injuries; human and material losses from accidents with bridge cranes.

At the same time, there are no comprehensive approaches that take into account the multifactorial nature of operating conditions and modern capabilities of stationary and portable diagnostic systems. Management of the functional state of the bridge foundry crane mechanism complex is possible after analyzing data on the actual state of each element, forming information messages, synthesizing knowledge about the technical condition to predict possible scenarios for damage development [18].

The aim of the work is to form a set of basic and additional, test and functional diagnostic parameters for periodicting inspections and constant monitoring of the technical condition of foundry cranes.

\section{Results and Discussion}

The technical system of the foundry crane includes subsystems (Figure 1): metal structures - including main, auxiliary and end beams; lifting mechanisms - main and auxiliary; movement mechanisms - bogies and bridge travel; control system. The system is recoverable in fixed periods; the maintenance-inspections are repentedly carried out, such as the inspections of components lubrication, tightening of threaded connections, etc.

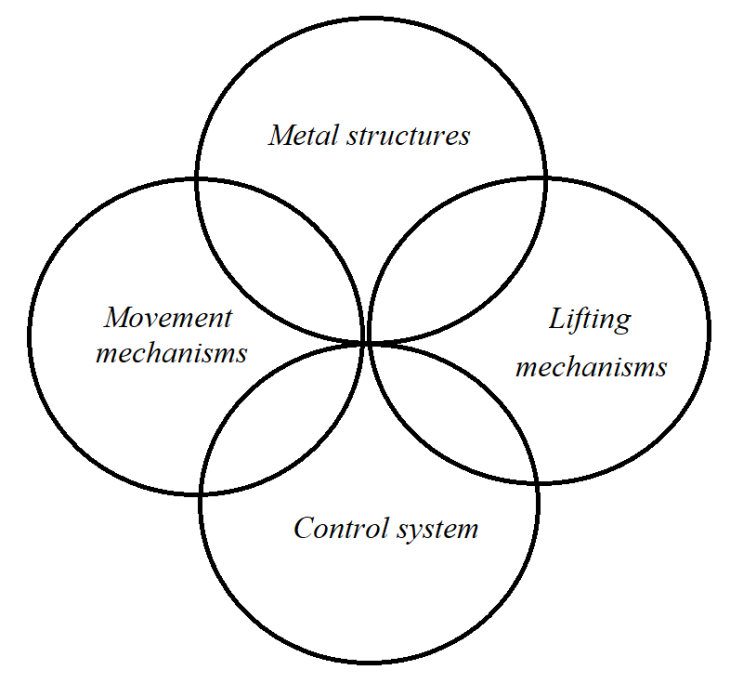

Figure 1. Technical subsystems of the foundry crane.

Operating conditions of the crane include the impactrepeated-short-term power loads, thermal - from molten metal, the environment of increased dustiness. Steelmelting in electric steelmaking involves the participation of two special metallurgical cranes: loading and casting. The main function of the loading crane is to feed the filling bucket to the electric arc furnace, load the furnace with scrap metal, and bulk materials. The frequency of work is 3...4 loadings per hour.

The casting crane transports the ladle with molten metal to the vacuum vessel and to the continuous casting machine. The frequency of work is $40 \ldots 60$ cycles per day. The work of casting crane in the similar converter steelmaking process to the work in the electric furnace steelmaking, the loading crane executes the loading of scrap metal and cast iron in the process of each melting.

Metal structures are subjected to cyclic loads that lead to appearance of fatigue cracks at the joints of the main girders and leadstocks, in the joints of balance-beams, etc. The reliability of foundry cranes with a load capacity of $110 \ldots 450$ tons is limited by the condition of metal structures which are non-recoverable elements.

Electromechanical subsystems of lifting and moving mechanisms could commonly fail. The causes of failures are associated with various models of failures implemented in bearings and gears of gearboxes, in brake units, couplings, ropes, lower blocks of polispastes located on the traverse of the hook suspension. The runners and the bearings of the lower pulley blocks are mostly affected by the temperature conditions. When moving the crane, uncertain dynamic loads may occur, as well as distortions of metal structures due to uneven operation of the movement mechanisms. Vibration during the operation of the lifting mechanism can also cause additional loads on metal structures.

Modern crane control systems are the systems of the first generation, they are simple and economically inefficient [19]. The control is carried out by the "on-off" function. The elements of the 2nd generation (maximum current protection, limit switches for limiting the stroke and lifting) and 
elements of the 3rd generation (motor speed control) are available. To ensure the synchronous operation of mechanisms with a separate drive, it is appropriate to use the electronic control systems, namely frequency converters and synchronization systems. Electrical control circuits of cranes do not provide functions for diagnosing the technical condition of equipment and metal structures of the crane.

The experience of "VNIIPTMASH", and statistics of foundry cranes of the Oskol Electrometallurgical Combine, show that the "weak links" of metallurgical cranes, especially foundry cranes, are: relay-contactor control system and reducers of the main lifting mechanism [20]. These "weak links" have different time rate of change, and the assessment check of their condition is carried out with mandatory frequency by the specialists of certain qualifications [21].

Assessment check of the hawser condition is carried out:

a. By the crane operator during a daily inspection, regular by a video image of the process of hawser reeling and winding from the drum;

b. Weekly during inspection by the repair service master;

c. Constantly, measuring the thermal heating cycles of the traverse of the hook suspension with a pyrometer, which allows to define the number of cycles of heat exposure and its intensity-for predicting the thermal resistance of the hawser;

d. Obtaining data of a thermal situation with the help of a thermal imager repeatedly provides data on the intensity of heating of metal structures by operation cycles;

e. The condition of the bearings of the lower polispast blocks installed on the traverse of the hook suspension is carried out regularly by means of a test lifting with or without a load according to piezoelectric sensors with memory units installed on the axes of the polispast blocks;

f. Every 3...6 months when using magnetic methods of non-destructive testing for flaw detection of hawsers.

g. The condition of metal structures is monitored:

h. Monthly by the driver and weekly by the repair service master;

i. Constantly by the strain monitoring system-including a laser and a measuring displacement matrix (Figure 2);

\section{Laser $\quad$ Laser beam Measuring matrix}

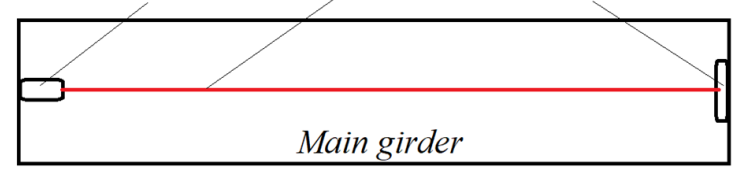

a)

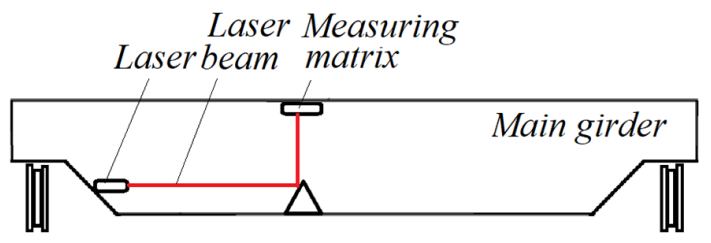

b)

Figure 2. Laser strain monitoring system: a) when moving the crane; b) when lifting the load. j. The duplication of the strain monitoring system is carried out by the acceleration control system of metal structures-which allows you to estimate the loads impact on the metal structure by the value of accelerations. This serves as the basis for the load cycle counter (Figure 3);

\section{Main girder}

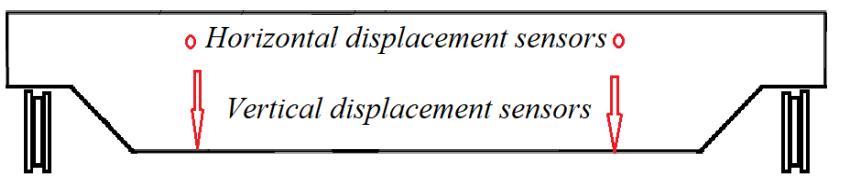

Figure 3. Acceleration control system for metal structures.

k. Technical inspection is carried out the visual-optical method with the application of quadrocopters, crawlers and video endoscopes, non-destructive testing methods: capillary, magnetic (control of residual magnetization), eddy current, ultrasonic, acoustic emission, etc., control of elastic and residual strain during static and dynamic tests using laser rangefinders.

The condition of the lifting mechanism is monitored:

a. Weekly, for the visual inspection of the gear train through the inspection hatches of the gearbox, brakes and coupling couplings by the repair service master;

b. Constantly using a vibration monitoring system with a minimum number of sensors installed in the lower part of the gearbox housing and fixing the vibration values in the lifting and lowering modes for comparison and decision-making;

c. Repeatedly with the help of a multi-channel vibration measuring system with additional checking of the stiffness of the main beams by measuring vibration at the extreme and middle position of the cargo truck (Figure 4).

Regular vibration monitoring based on portable data collectors requires the presence of an operator beside the mechanisms, which is not allowed. Constant monitoring with the help of stationary systems leads to the collecting of a large array of information that requires operational processing - this problem has not found its solution yet. A possible solution is to use the universal multichannel measurement system UMS-16 (Figure 5) in conjunction with the SAFE PLANT software.

The condition of the bridge movement mechanism is monitored:

a. Weekly, the visual inspection of the gear train through the inspection hatches of the gearbox, brakes and joint sleeves is carried out by the repair service master;

b. Constantly using a vibration monitoring system with a minimum number of sensors installed in the upper part of the gearbox housing and fixing the vibration values when changing the direction of rotation to assess the overall wear, a comparative assessment of time implementations will eliminate the influence of rail track defects on the vibration of mechanisms;

c. Repeatedly using a multi-channel vibration measuring system.

This approach can be used to monitor the condition of the 
movement mechanisms of the main and additional lifting trolleys. The design of the investigated mechanism of the main hoist of the casting crane is a single-drum circuit driven by two gearboxes and motors with electrical synchronization of rotation.

Vibration parameters were measured using a $795 \mathrm{M}$ vibration analyzer and a piezoaccelerometer installed on the housing of one of the gearboxes, in two modes: spectral analysis of vibration acceleration in the frequency range $10 \ldots 1000 \mathrm{~Hz}, 1600$ lines; recording of the time realization of the vibration acceleration signal with a period of 200 microseconds, 16000 measurements.

The example of spectral analysis of vibration components is shown in Figure 6a It indicates possible damage on the working surface of the gear teeth, the level of damage is initial. The recorded pulsations of the vibration signal with a large amplitude range during the development of damage (Figure 6b) were not specified in the spectral analysis due to the low frequency and corresponded to damage to a slowspeed gear train.
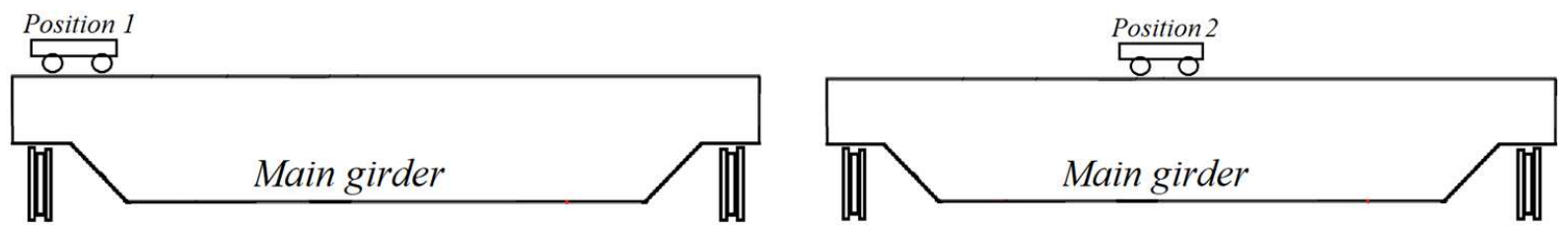

Figure 4. Positions of the main truck while measuring the vibration of the lifting mechanism to assess the stiffness of the main beams.

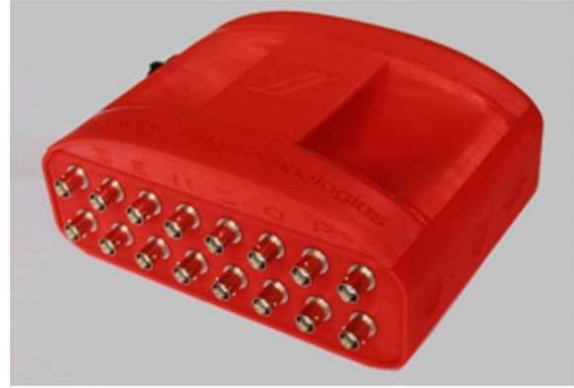

a)
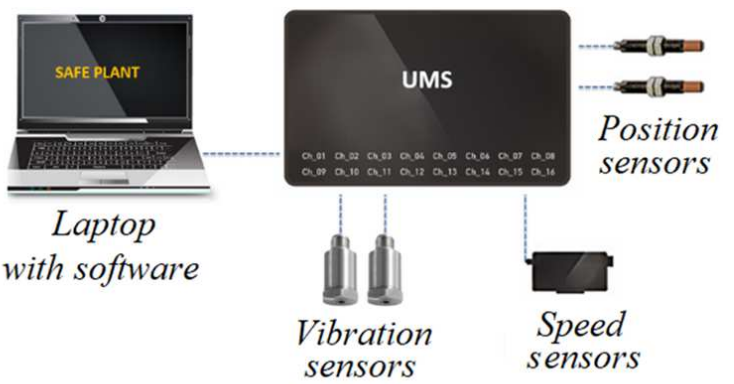

b)

Figure 5. Measuring unit of the universal multichannel measuring system UMS-16 (a), schematic diagram of the UMS-16 complex in conjunction with the SAFE PLANT software (b).

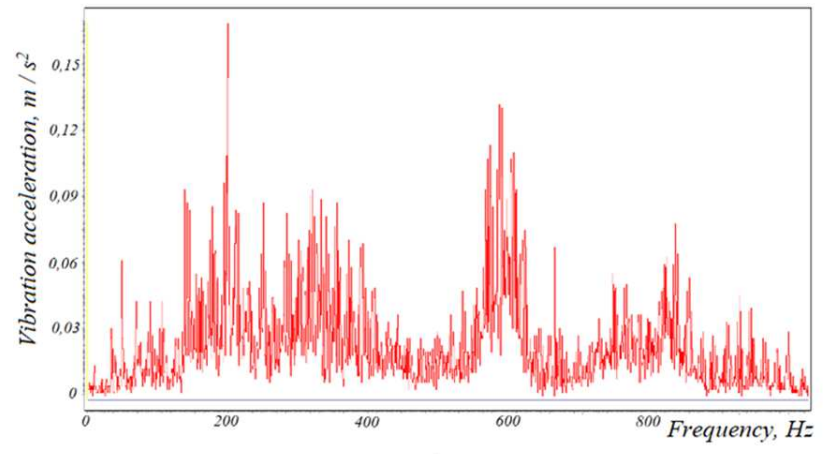

a)

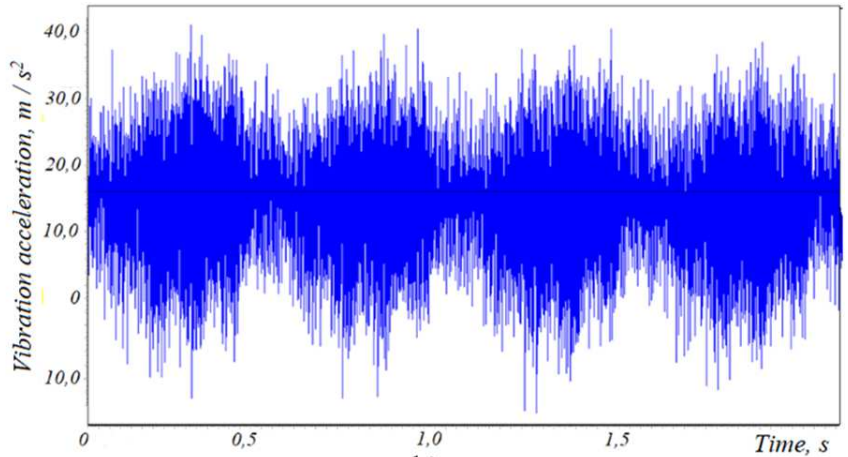

b)

Figure 6. Fragments of vibration signals from the gear reducing box sensors: a) vibration acceleration spectrum; b) realization time.

Automation systems allow to obtain a number of diagnostic parameters:

a. Control of current values and rotation speed allows to carry out a comparative analysis of the loading stability of the lifting and movement mechanism engines;

b. Monitoring of current derivatives allows to implement an effective current protection that is triggered earlier than the usual threshold setpoint;

c. The ability to control the actual power consumption of the lifting engines, the speed and mass of the lifted load allows to calculate the actual efficiency and compare it with the reference surface (Figure 7) Efficiency $=f(Q$, v), to obtain an indicator of the technical condition.

Well-known fact is a decrease in the values of the efficiency of crane mechanisms, in particular the lifting mechanism, with a decrease in the load and with a decrease in the lifting speed. In the course of industrial tests of a serviceable lifting mechanism of a 275-ton $\left(Q_{H}\right)$ casting crane when lifting loads of different weights $Q$ at different speeds $v$, the values of the torque $M$ on the engine shaft and the rotation speed $\omega$ were recorded, using an automation system. The data obtained made it possible to calculate the actual values of the lifting mechanism efficiency according to well-known formulas and present them in the table 1: 
where $g$ is the acceleration due to gravity.

Table 1. Calculation data of the actual efficiency of the hoist mechanism.

\begin{tabular}{|c|c|c|c|c|c|}
\hline Lifting efficiency & $v_{1} 20 \%$ & $v_{2} 40 \%$ & $v_{3} 60 \%$ & $v_{4} 80 \%$ & $v_{5} 100 \%$ \\
\hline $\begin{array}{l}27 \mathrm{~T} \\
Q / Q H=27 / 275=0,098\end{array}$ & 0,465 & 0,394 & 0,330 & 0,292 & 0,269 \\
\hline $\begin{array}{l}241 \mathrm{~T} \\
Q / Q_{H}=241 / 275=0,876\end{array}$ & 0,798 & 0,696 & 0,659 & 0,632 & 0,619 \\
\hline $\begin{array}{l}262 \mathrm{~T} \\
Q / Q H=262 / 275=0,953\end{array}$ & 0,778 & 0,697 & 0,669 & 0,650 & 0,634 \\
\hline $\begin{array}{l}304 \mathrm{~T} \\
Q / Q H=304 / 275=1,105\end{array}$ & 0,832 & 0,741 & 0,707 & 0,688 & 0,679 \\
\hline $\begin{array}{l}330 \mathrm{~T} \\
Q / Q_{H}=330 / 275=1,2\end{array}$ & 0,841 & 0,753 & 0,721 & 0,703 & 0,694 \\
\hline
\end{tabular}

The presented data are approximated by a dependence of the form:

$$
\text { Efficiency }=a+b \cdot \ln (\mathrm{Q} / \mathrm{QH})+c /(\mathrm{v} / \mathrm{vH}),
$$

where $a=0,614 ; b=0,154 ; c=0,04-$ regression coefficients.

The correlation coefficient is 0.992. A graphical representation of the dependence is shown in Figure 7. The resulting dependence remains unchanged in good condition and gets distorted when damage occurs. This allows the use of efficiency as a primary diagnostic feature.

In general, it is possible to formulate, we can formulate the axioms of the functional state for each element, which will consider the choice of diagnostic parameters and the frequency of their determination. At the same time, a list of operational impacts that lead to the loss of working condition is formed.

Operating capacity of electric part is ensured by the constant parameters of conductivity and insulating properties of the system; stable parameters of electrical quantities (current, voltage) and temperature of the nodes not exceeding the acceptable values, the implementation of the specified functions during the regulating, absence of sparking.

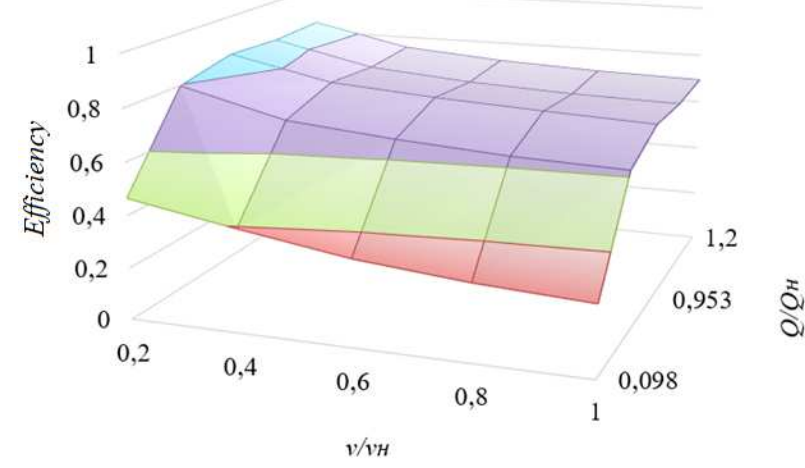

Figure 7. Reference surface of Efficiency $=f(Q, v)$.

The functional state of the mechanical part is characterized by the following features: low vibration and noise; smooth operation, absence of shocks and tossing's when changing the direction of rotation; body frame temperature should not exceed the limit values; absence of impact failure processes; tightened threaded connections; absence of oil leakage and cracks in the body parts of metal structures.

\section{Conclusion}

The use of methods of continuous technical diagnostics and non-destructive testing allows to obtain reliable information about the technical condition of the "weak links" of the foundry crane.

The examples of continuous technical diagnostics of metal structures and lifting mechanisms show that currently there is a reliable instrument equipment, tested in real conditions of metallurgical production.

Power-law relationships have been obtained between the load, the lifting speed and the efficiency of the main lift mechanism of a casting crane, which allows using efficiency as a primary diagnostic feature.

A large array of data, in the form of a constant stream from various sensors, requires the developing of diagnostic data processing centers for processing and making operational decisions to ensure the working condition of the foundry crane.

\section{References}

[1] Sidorov, V. A. Analysis of modern designs of lifting mechanisms for casting cranes / V. A. Sidorov, E. V. Oshovskaya, N. A. Chentsov // Mechanical equipment of metallurgical plants: Intern. Sat. scientific. tr. / ed. Korchunova A. G. Vol. 3. - Magnitogorsk: Magnitogorsk Publishing House. state tech. un-ta them. G. I. Nosova, 2014. S. 87-94. (Сидоров, В. А. Анализ современных конструкций механизмов подъёма литейных кранов / В. А. Сидоров, Е. В. Ошовская, Н. А. Ченцов // Механическое оборудование металлургических заводов: Междунар. сб. науч. тр. / под ред. Корчунова А. Г. Вып. 3. - Магнитогорск: Изд-во Магнитогорск. гос. техн. унта им. Г. И. Носова, 2014. С. 87-94.).

[2] RD 10-112-5-97 Methodical guidelines for the inspection of bridge-type cranes in order to determine the possibility of their further operation. Part 5. Bridge and gantry cranes. (РД 10-112-5-97 Методические указания по проведению обследования кранов мостового типа с целью определения возможности их дальнейшей эксплуатации. Часть 5. Краны мостовые и козловые.). 
[3] PB-10-382-00. Rules for the construction and safe operation of cranes. - SPb.: Publishing house DEAN, 2003-- $272 \mathrm{p}$. (ПБ-10-382-00. Правила устройства и безопасной эксплуатации грузоподъемных кранов. - СПб.: Издательство ДЕАН, 2003. - 272 с.).

[4] Haniszewski T., Gaska D. Overhead traveling crane vibration research using experimental wireless measuring system / TRANSPORT PROBLEMS 2013 Volume 8 Issue 1, P. 57-66.

[5] Fidrovskaya, N. N., Slepuzhnikov E. D., Chernyshenko A. V., Varchenko I. S. New design of traveling wheels of bridge cranes [Text] // Modern trends in technical sciences: materials of the IV Intern. scientific. conf. (Kazan, October 2015). - Kazan: Buk, 2015 -- S. 66-70. - URL https://moluch.ru/conf/tech/archive/163/8878/ (date of access: 06.11.2019). (Фидровская, Н. Н., Слепужников Е. Д., Чернышенко А. В., Варченко И. С. Новая конструкция ходовых колес мостовых кранов [Текст] // Современные тенденции технических наук: материалы IV Междунар. науч. конф. (г. Казань, октябрь 2015 г.). Казань: Бук, 2015. - C. 66-70. — URL https://moluch.ru/conf/tech/archive/163/8878/ (дата обращения: 06.11.2019).).

[6] Aleksandrov, M. P Load-lifting machines / M. P. Aleksandrov. M.: Higher. shk., 2000, 552s. (Александров, М. П Грузоподъёмные машины / М. П. А лександров. М.: Высш. шк., 2000, - 552 с.).

[7] Lobov N. A. Dynamics of movement of cranes on a rail track / N. A. Lobov - M. Iz-vo MGTU, 2003. 232 р. (Лобов Н. А. Динамика передвижения кранов по рельсовому пути / Н. А. Лобов - М. Из-во МГТУ, 2003. - 232 с.).

[8] http: // www tst-spb.ru >products / crane / Systems for vibration diagnostics and vibration control of crane equipment. (http://www tst-spb.ru>products/crane / Системы вибродиагностики и виброконтроля кранового оборудования.).

[9] Ivanov, V. N. Technical diagnostics of hoisting-andtransport machines and equipment: Monograph / Ivanov V. N. - Kh.: Publishing house "INDUSTRIA", 2009. - 204 p. (Иванов, В. Н. Техническое диагностирование подъёмно-транспортных машин и оборудования: Монография / Иванов В. Н. - Х.: Изд-во «ИНДУСТРИЯ», 2009. - 204 с.).

[10] Zaretsky, A. A. Strategy for determining the residual life of cranes // Lifting structures. Special equipment. 2002. No. 11. S. 21-23. (Зарецкий, А. А. Стратегия определения остаточного ресурса грузоподъемных кранов // Подъёмные сооружения. Специальная техника. 2002. №11. - C. 21-23.).

[11] Kotelnikov, B. C., Eremin A. Yu., Zaretskiy A. A., Korotkiy A. A. The concept of assessing the residual life of metal structures of cranes that have worked out the standard period // Labor safety in industry. 2000. No. 10. S. 41-46. (Котельников, В. С., Еремин А. Ю., Зарецкий А. А., Короткий А. А. Концепция оценки остаточного ресурса металлических конструкций грузоподъемных кранов, отработавших нормативный срок // Безопасность труда в промышленности. 2000. - №10. - C. 41-46.).

[12] Popov, V. G., Malov V. V., Lopatenko R. V., Zhigulina T. N. Improving the reliability of casting cranes // Steel. 2002, no.
4, p. 76-78. (Попов, В. Г., Малов В. В., Лопатенко Р. В., Жигулина Т. Н. Повышение надежности литейных кранов // Сталь. 2002, №4, с. 76-78.).

[13] Popov, VG Influence of temperature influences on heating of metal structures of a casting crane / VG Popov, ZK Kabakov, DF Gabtykaev // Steel. 2009. -№ 2. - S. 53-54. (Попов, В. Г. Влияние температурных воздействий на нагрев металлоконструкции литейного крана / В. Г. Попов, З. К. Кабаков, Д. Ф. Габтыкаев // Сталь. - 2009. № 2. - С. 53-54.).

[14] Popov, VG Influence of gas emissions during converter smelting on the reliability of steel ropes of casting cranes / VG Popov, DF Gabtykaev, A. S. Lipatov, VV Malov // Repair, restoration, modernization. - 2007. No. 2. S. 45-47. (Попов, В. Г. Влияние выбросов газа при конвертерной плавке на надежность стальных канатов литейных кранов / В. Г. Попов, Д. Ф. Габтыкаев, А. С. Липатов, В. В. Малов // Ремонт, восстановление, модернизация. 2007. - № 2. - C. 45-47.).

[15] Popov, VG Defects of metal structures of casting cranes and ways to eliminate them / VG Popov, DF Gabtykaev // Labor safety in industry. - 2009 - No. 4 - Р. 18-20. (Попов, В. Г. Дефекты металлоконструкций литейных кранов и пути их устранения / В. Г. Попов, Д. Ф. Габтыкаев // Безопасность труда в промышленности. - 2009 - №4 - С. 18-20.).

[16] Gabtykaev, DF Analysis of defects in steel ropes of casting cranes / DF Gabtykaev, VG Popov, H. H. Kravnik, SM Shagokhin // Progressive processes and equipment of metallurgical production: Materials of international. nauchn.-ekhn. conf., having eaten. To the 50th anniversary of OAO Severstal. Part 1. -Cherepovets, 2005 -- S. 64-67. (Габтыкаев, Д. Ф. Анализ дефектов стальных канатов литейных кранов / Д. Ф. Габтыкаев, В. Г. Попов, Н. Н. Кравник, С. М. Шагохин // Прогрессивные процессы и оборудование металлургического производства: Материалы междунар. науч.-оехн. конф., поев. 50летию ОАО «Северсталь». Ч. 1. -Череповец, 2005. - С. 64-67.).

[17] Efimov, I. S., Popov V. G., Kuzminov A. L., Malov V. V. On-board control system "BORT-1" of thermal cyclic loads and loads on the elements of casting cranes in the KP of JSC "Severstal" / / Severstal - Ways to Improvement: Conference Proceedings - Cherepovets, 2001. - pp. 49-52. (Ефимов, И. С., Попов В. Г., Кузьминов А. Л., Малов В. В. Бортовая система контроля «БОРТ-1» термоциклических нагрузок и нагружений на элементы литейных кранов в КП ОАО «Северсталь» // «Северсталь» - пути к совершенствованию: Материалы конференции Череповец, 2001. - С. 49-52.).

[18] Gertsbach, IB, Kordonskiy Kh. B. Models of refusals. Ed. B. V. Gnedenko, M.: "Soviet radio", 1966. - 166 p. (Герцбах, И. Б., Кордонский Х. Б. Модели отказов. Под ред. Б. В. Гнеденко, М.: «Советское радио», 1966. - 166 c.).

[19] Classification of control systems for crane equipment / Poverty V. V., Grigoriev E. V., Svistelnik A. V. et al. // Metallurgical processes and equipment. - 2009. - No. 1. - S. 29-34. (Классификация систем управления крановым оборудованием / Нищета В. В., Григорьев Е. В., Свистельник А. В. и др. // Металлургические процессы и оборудование. - 2009. - №1. - С. 29-34.). 
[20] Gennady Filatov. Reconstruction of metallurgical cranes. Relevance.

$$
\text { Practical }
$$

experience. https://pandia.ru/user/publ/223-

Rekonstruktciya_metallurgicheskih_kranov_Aktualmznost mz_Prakticheskij_opit (Геннадий Реконструкция металлургических кранов. Актуальность. Практический опыт. https://pandia.ru/user/publ/223Rekonstruktciya_metallurgicheskih_kranov_Aktualmznost mz_Prakticheskij_opit).

[21] Penchuk, V. A. Improving the safety of work and labor protection on hoisting machines used on the surface of coal mining enterprises / V. A. Penchuk, V. N. Gusakov, N. A. Yurchenko // collection "Methods and means of creating safe and healthy working conditions in coal mines ".- 2019.No. 1 (44) - pp. 65-73. (Пенчук, В. А. Повышение безопасности работ и охраны труда на грузоподъемных машинах, используемых на поверхности угледобывающих предприятиях/ В. А. Пенчук, В. Н. Гусаков, Н. А. Юрченко// сборник «Способы и средства создания безопасных и здоровых условий труда в угольных шахтах».- 2019.- № 1 (44).- С. 65-73.). 